\title{
Observed EI Niño conditions in the eastern tropical Pacific in October 2015
}

\author{
Lothar Stramma $^{1}$, Tim Fischer ${ }^{1}$, Damian S. Grundle ${ }^{1, a}$, Gerd Krahmann ${ }^{1}$, Hermann W. Bange ${ }^{1}$, and \\ Christa A. Marandino ${ }^{1}$ \\ ${ }^{1}$ GEOMAR Helmholtz Centre for Ocean Research Kiel, Düsternbrooker Weg 20, 24105 Kiel, Germany \\ anow at: Bermuda Institute of Ocean Sciences (BIOS), 17 Biological Station, St George's GE 01, Bermuda
}

Correspondence to: Lothar Stramma (lstramma@geomar.de)

Received: 11 March 2016 - Published in Ocean Sci. Discuss.: 24 March 2016

Revised: 6 June 2016 - Accepted: 10 June 2016 - Published: 4 July 2016

\begin{abstract}
A strong El Niño developed in early 2015. Measurements from a research cruise on the R/V Sonne in October 2015 near the Equator east of the Galapagos Islands and off the shelf of Peru are used to investigate changes related to El Niño in the upper ocean in comparison with earlier cruises in this region. At the Equator at $85^{\circ} 30^{\prime} \mathrm{W}$, a clear temperature increase leading to lower densities in the upper $350 \mathrm{~m}$ had developed in October 2015, despite a concurrent salinity increase from 40 to $350 \mathrm{~m}$. Lower nutrient concentrations were also present in the upper $200 \mathrm{~m}$, and higher oxygen concentrations were observed between 40 and $130 \mathrm{~m}$. In the equatorial current field, the Equatorial Undercurrent (EUC) east of the Galapagos Islands almost disappeared in October 2015, with a transport of only $0.02 \mathrm{~Sv}$ in the equatorial channel between $1^{\circ} \mathrm{S}$ and $1^{\circ} \mathrm{N}$, and a weak current band of $0.78 \mathrm{~Sv}$ located between 1 and $2^{\circ} 30^{\prime} \mathrm{S}$. Such neardisappearances of the EUC in the eastern Pacific seem to occur only during strong El Niño events. Off the Peruvian shelf at $\sim 9^{\circ} \mathrm{S}$, characteristics of upwelling were different as warm, saline, and oxygen-rich water was upwelled. At $\sim 12$, $\sim 14$, and $\sim 16^{\circ} \mathrm{S}$, the upwelling of cold, low-salinity, and oxygen-poor water was still active at the easternmost stations of these three sections, while further west on these sections a transition to El Niño conditions appeared. Although from early 2015 the El Niño was strong, the October measurements in the eastern tropical Pacific only showed developing El Niño water mass distributions. In particular, the oxygen distribution indicated the ongoing transition from "typical" to El Niño conditions progressing southward along the Peruvian shelf.
\end{abstract}

\section{Introduction}

The El Niño-Southern Oscillation (ENSO) cycle of alternating warm El Niño and cold La Niña events is the dominant year-to-year climate signal on earth. ENSO originates in the tropical Pacific through interaction between the ocean and the atmosphere, but its environmental and socioeconomic impacts are felt worldwide (McPhaden et al., 2006). In the eastern tropical South Pacific, El Niño events strongly influence the commercial fishery and weather and impact on the economics and living conditions.

The strongest El Niño events since 1950 were observed in the years 1982/83 and 1997/98, the latter also referred to as "the climate event of the twentieth century" (Changnon, 2000). Climate models suggest a doubling in the occurrences of extreme El Niño events in the future in response to greenhouse warming (Cai et al., 2015). In early 2015, an El Niño with strength similar to the 1997/98 El Niño developed. Sea surface temperature anomalies were strongest along the Equator and the tropical North Pacific, while the development of a temperature anomaly in the eastern tropical Pacific off Peru was, according to NOAA's "ENSO diagnostic discussion archive", strong in April and May, and then weakened and intensified again from August to October 2015.

El Niño dynamics modulate near-surface temperature, salinity, and density, as well as the mixed layer depth, oxycline depth, and the vertical extent of the low oxygen layer (e.g., Fuenzalida et al., 2009). In the eastern Pacific, ENSO variability is most pronounced along the Equator and the coasts of Ecuador and Peru (Wang and Fiedler, 2006), but also off Chile (e.g., Ulloa et al., 2001). Weaker trade winds 
during El Niño conditions result in a weaker equatorial circulation with a generally observed weakening or disappearance of the Equatorial Undercurrent (EUC) (Kessler and McPhaden, 1995; Johnson et al., 2002). During the height of an El Niño event, the EUC episodically disappears in the western and central Pacific and partially reverses (Firing et al., 1983; McPhaden et al., 1990; Johnson et al., 2000; Izumo, 2005), while in the eastern Pacific, episodic disappearance of the EUC seems rare (Halpern, 1987; McPhaden and Hayes, 1990; Seidel and Giese, 1999; Johnson et al., 2000; Izumo, 2005). El Niño events lead to a pronounced eastward extension of the western Pacific warm pool and to a development of atmospheric convection, and hence a rainfall increase, in the usually cold and dry eastern Pacific (Cai et al., 2015).

Past El Niño events have been observed to have different local occurrences and parameter distributions in recent years. There has been evidence of an increased occurrence of El Niño events in the central Pacific called Central Pacific (CP) El Niño or "El Niño Modoki" (e.g., Ashok and Yamagata, 2009; Dewitte et al., 2012), different from the cold tongue, or Eastern Pacific (EP), El Niño events that develop in the eastern Pacific. For a typical CP El Niño, the largest sea surface temperature (SST) increase occurs at the Equator between $130^{\circ} \mathrm{W}$ and $160^{\circ} \mathrm{E}$, while cooling appears off the shelf of Peru. For the EP El Niño the SST increases at the Equator east of $180^{\circ} \mathrm{W}$ to South America and southward along the South American coast to Chile (e.g., Dewitte et al., 2012).

In the eastern tropical South Pacific (ETSP), a subsurface low oxygen zone exists with a pronounced minimum in oxygen at $\sim 100$ to $500 \mathrm{~m}$ depth and is referred to as an oxygen minimum zone (OMZ) or oxygen deficient zone (ODZ). This ODZ is suboxic (oxygen concentrations below $\sim 4.5-$ $10.0 \mu \mathrm{mol} \mathrm{kg}{ }^{-1}$; e.g., Karstensen et al., 2008; Stramma et al., 2008). In suboxic regions nitrate and nitrite become involved in respiration processes such as denitrification or anammox (e.g., Kalvelage et al., 2013). In the eastern equatorial Pacific the oxygen content has been shown to increase during El Niño events in the upper 300 to $350 \mathrm{~m}$ in the equatorial channel (e.g., Fuenzalida et al., 2009; Czeschel et al., 2012), as well as off the Peruvian coast (e.g., Helly and Levin, 2004). Coastal winds during El Niño events are usually upwelling favorable, and thus could not produce the observed warming (Kessler, 2006). Coastal warming during El Niño is caused by downwelling Kelvin waves generated by mid-Pacific westerly wind anomalies that deepen the eastern thermocline, nutricline, and oxycline and allow warming to occur, independent of the local winds (Kessler, 2006). Consequently, during El Niño events the upwelled water off Peru is warmer, more oxygen replete and less nutrient rich. El Niño, in general, results in a depressed thermocline and thus reduced rates of macronutrient supply and primary production (Pennington et al., 2006) off Peru, which also contributes to an oxygen increase on the shelf (Gutiérrez et al., 2008). In the case of strong El Niño events when the oxygen

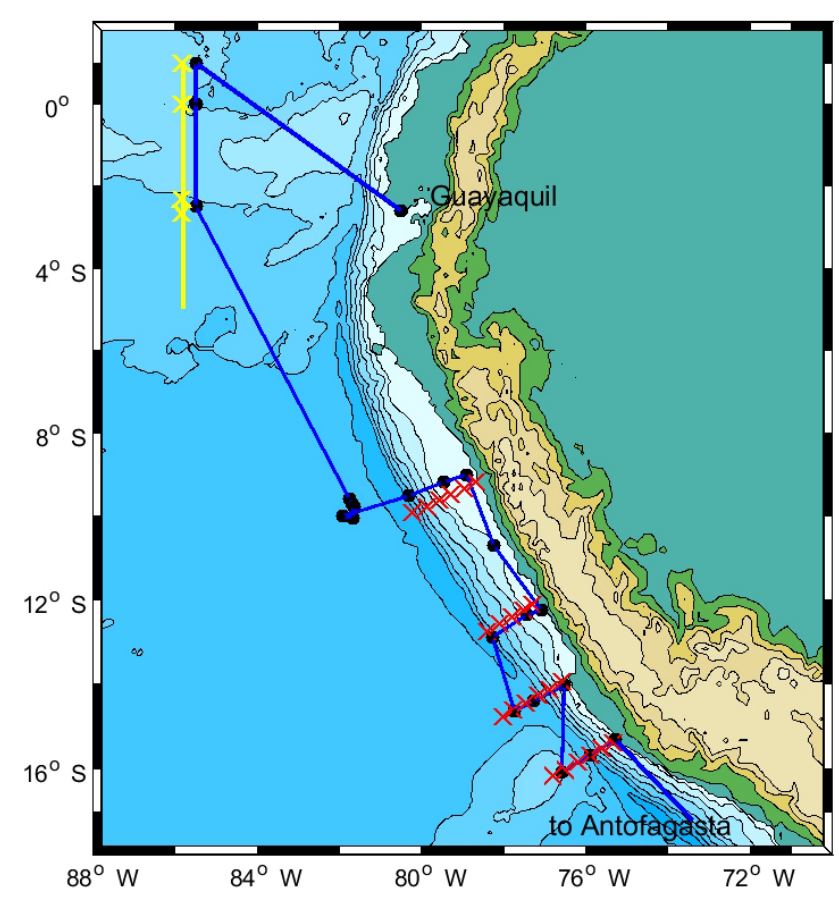

Figure 1. Cruise track (blue line) and CTD (conductivitytemperature-depth) stations (black circles) of cruise R/V Sonne from Guayaquil 5 October to Antofagasta 22 October 2015, as well as equatorial stations March 1993, February 2009, and November 2012 (yellow “x”), CTD sections off Peru December 2012 (red "x"), and ADCP sections across the Equator (yellow line). Topography (color) with depth/height contours in $1000 \mathrm{~m}$ intervals enhanced by the $200 \mathrm{~m}$ depth contour.

concentration above the shelf bottom increases from about zero to $>40 \mu \mathrm{mol} \mathrm{kg}-1$, the sediments respond with tremendous changes in ecological state (Gutiérrez et al., 2008). At a time-series station at $\sim 12^{\circ} \mathrm{S}, 77^{\circ} 30^{\prime} \mathrm{W}$ off Lima from 1996 to 2010 for temperature, salinity, density, oxygen, and nutrients, the influence of El Niño - especially the strong 1997/98 El Niño - is clearly visible, with higher temperature, salinity, and oxygen, and lower density, nitrite, silicate, and phosphate (Graco et al., 2016).

Here we use measurements from an R/V Sonne research cruise in October 2015 (Fig. 1) from a section across the Equator east of the Galapagos Islands and from four sections off the Peruvian shelf, to investigate changes in the upper ocean related to the strong 2015 El Niño in comparison with earlier cruises in this region. The aim is to unravel the progress of the transition to El Niño conditions in the eastern Pacific several months after the start of the El Niño.

\section{Data sets and methods}

In October 2015 an R/V Sonne transit cruise (So243; 5 to 22 October 2015) from Guayaquil, Ecuador, to Antofagasta, Chile, was carried out (Fig. 1) (short cruise report available 
at https://www.ldf.uni-hamburg.de/sonne/wochenberichte/ wochenberichte-sonne/so242-243/so243-scr.pdf), which allowed us to investigate possible El Niño signals at the Equator near $85^{\circ} 30^{\prime} \mathrm{W}$ and off the shelf of Peru at sections perpendicular to the shelf at $\sim 9, \sim 12, \sim 14$, and $\sim 16^{\circ} \mathrm{S}$.

A Seabird CTD system with a GO (General Oceanics) rosette with $24 \times 10 \mathrm{~L}$ water bottles was used for water profiling and discrete water sampling. The CTD system was used with double sensors for temperature, conductivity (salinity), and oxygen. The dual CTD temperature sensors calibrated by the manufacturer are compared during the cruise so that the deviation is less than $0.002^{\circ} \mathrm{C}$, and the accuracy of the temperature measurements is estimated to be $0.002{ }^{\circ} \mathrm{C}$ or better. The CTD salinity calibration with salinometer salinity samples resulted in a rms uncertainty of 0.0011 . The CTD oxygen sensors were calibrated with oxygen measurements obtained from discrete samples from the rosette applying the classical Winkler titration method, using a non-electronic titration stand (Winkler, 1888; Hansen, 1999). The rms uncertainty of the CTD oxygen sensor calibration of cruise So243 was determined to be $\pm 0.8 \mu \mathrm{mol} \mathrm{kg}{ }^{-1}$. Oxygen concentrations of less than $3 \mu \mathrm{mol} \mathrm{kg}{ }^{-1}$ are not resolved by Winkler titration and values below $3 \mu \mathrm{mol} \mathrm{kg}{ }^{-1}$ were used as $0 \mu \mathrm{mol} \mathrm{kg}{ }^{-1}$ for the sensor calibration, as the $\mathrm{H}_{2} \mathrm{~S}$ smell of the water of related rosette bottles indicated $0 \mu \mathrm{mol} \mathrm{kg}{ }^{-1}$.

Nutrients were measured on-board with a QuAAtro autoanalyzer (Seal Analytical). Nitrite $\left(\mathrm{NO}_{2}^{-}\right)$, nitrate $\left(\mathrm{NO}_{3}^{-}\right)$, phosphate $\left(\mathrm{PO}_{4}^{3-}\right)$, and silicid acid $\left(\mathrm{Si}(\mathrm{OH})_{4}\right.$, referred to as silicate hereinafter) were measured with an analytical precision of $5.5,1.3,0.4$, and $0.5 \%$ respectively. The $\mathrm{N}: \mathrm{P}$ ratio used here was computed as $\mathrm{N}: \mathrm{P}=\left(\mathrm{NO}_{3}^{-}+\mathrm{NO}_{2}^{-}\right): \mathrm{PO}_{4}^{3-}$.

Two vessel-mounted acoustic Doppler current profilers (ADCP) were used to record ocean velocities in October 2015: an RDI OceanSurveyor $75 \mathrm{kHz}$ ADCP with $8 \mathrm{~m}$ bin spacing provided the velocity distribution to $\sim 650 \mathrm{~m}$ depth, while a $38 \mathrm{kHz}$ ADCP with $32 \mathrm{~m}$ bin spacing provided velocity profiles down to $\sim 1300 \mathrm{~m}$ depth. During the entire cruise the navigation data was of high quality. Due to the interest in the upper ocean, the higher-resolution $75 \mathrm{kHz}$ ADCP is used here.

Earlier crossings of the Equator (Table 1 and Fig. 1) were accomplished in March/April 1993 on R/V Knorr (Tsuchiya and Talley, 1998), in February 2009 on R/V Meteor (Czeschel et al., 2011), and in November 2012 on R/V Meteor (Stramma et al., 2013) at $85^{\circ} 50^{\prime} \mathrm{W}$. Sections across the Peruvian shelf between 9 and $16^{\circ} \mathrm{S}$ were made during R/V Meteor cruise M91 in December 2012 (Czeschel et al., 2015; Bange, 2013). Measurement accuracies during these cruises were similar to October 2015 and the details are described in the related literature. In contrast to October 2015, the CTD stations in 1993, 2009, and 2012 were not carried out at $2^{\circ} 30^{\prime} \mathrm{S}, 85^{\circ} 30^{\prime} \mathrm{W}$, but at $2^{\circ} 20^{\prime} \mathrm{S}$ and $2^{\circ} 40^{\prime} \mathrm{S}$ at $85^{\circ} 50^{\prime} \mathrm{W}$, and these two stations were combined for a mean profile at $2^{\circ} 30^{\prime} \mathrm{S}$. The sections across the Equator and off

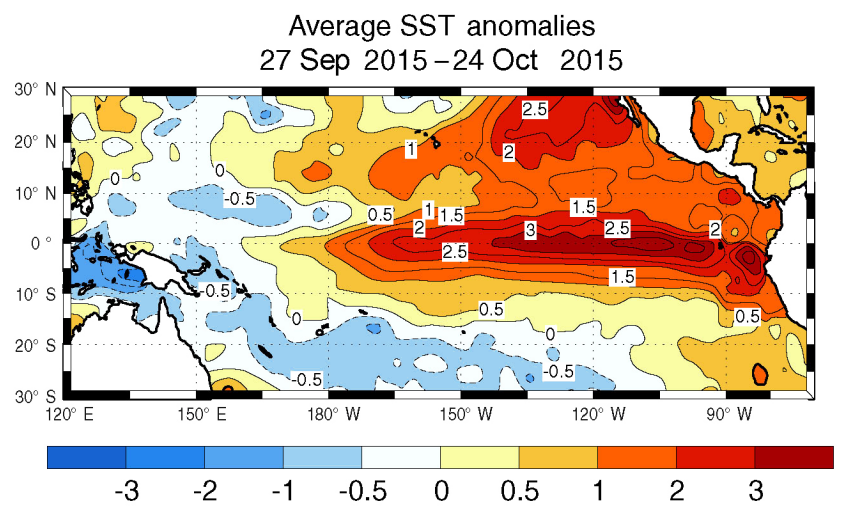

Figure 2. Average sea surface temperature anomalies in ${ }^{\circ} \mathrm{C}$ for the period 27 September to 24 October 2015. Image with permission from NOAA extracted from the http://www.cpc.ncep.noaa.gov/products/analysis_monitoring/ lanina/enso_evolution-status-fcsts-web.pdf file version from 26 October 2015, redrawn with very minor modifications to improve the figure quality.

the Peruvian shelf were not at identical geographical coordinates, but we expect that the offset will be small compared to the differences measured.

Different indices exist to describe the El Niño status and will be used here to determine the El Niño status at the time of the measurements. The NINO $1+2$ index is the temperature difference compared to the 1982-2005 climatological cycle in the eastern tropical Pacific $\left(0-10^{\circ} \mathrm{S}, 80-90^{\circ} \mathrm{W}\right)$, and is close to the region of the measurements used here. The Oceanic Niño Index (ONI) has become a standard for identifying El Niño and La Niña events. It is a running 3-month mean SST anomaly for the Niño 3.4 region (i.e., $5^{\circ} \mathrm{N}-5^{\circ} \mathrm{S}$, $120-170^{\circ} \mathrm{W}$ ) related to the 1981-2010 base period. Events are defined as five consecutive overlapping 3-month periods at or above the $0.5^{\circ} \mathrm{C}$ anomaly for warm $\mathrm{El} \mathrm{Niño} \mathrm{events,} \mathrm{and}$ at or below the $-0.5^{\circ} \mathrm{C}$ anomaly for cold La Niña events.

\section{The El Niño in 2015}

The SST anomaly for 27 September 2015 to 24 October 2015 was strong along the Equator to the South American continent and southward off the Peruvian coast (Fig. 2). The NINO $1+2$ index was high at +2.52 in October 2015 (Table 1); hence, the 2015 El Niño is a clear EP El Niño. The SST distribution in fall 2015 shows a strong and prominent SST increase along central America and in the eastern North Pacific at $20-25^{\circ} \mathrm{N}$ that differs from the typical EP El Niño distribution. This feature, also known as "The Blob", is an unrelated positive temperature anomaly that developed in 2013 in the Gulf of Alaska and progressed along the North American continent to the $20-25^{\circ} \mathrm{N}$ region in mid2015 (Kintisch, 2015). 
Table 1. Time and geographical location of CTD data used in this study and the NINO $1+2$ and ONI indices for the months of observation or for 2 months for measurements carried out at the end or beginning of a month listed in the tables (http://www.cpc.ncep.noaa.gov/data/ indices/sstoi.indices and http://www.cpc.ncep.noaa.gov/products/analysis_monitoring/ensostuff/ensoyears.shtml).

\begin{tabular}{llll}
\hline Time & Location & NINO $1+2$ & ONI \\
\hline 29-31 Mar 1993 & $1^{\circ} \mathrm{N}-2^{\circ} 40^{\prime} \mathrm{S}$ & $+0.65 \mathrm{Mar},+0.97 \mathrm{Apr}$ & $+0.5 \mathrm{March},+0.7 \mathrm{Apr}$ \\
12-13 Feb 2009 & $1^{\circ} \mathrm{N}-2^{\circ} 40^{\prime} \mathrm{S}$ & -0.11 & -0.7 \\
1-3 Nov 2012 & $1^{\circ} \mathrm{N}-2^{\circ} 40^{\prime} \mathrm{S}$ & $-0.11 \mathrm{Oct},-0.38 \mathrm{Nov}$ & $+0.4 \mathrm{Oct},+0.2 \mathrm{Nov}$ \\
7-8 Oct 2015 & $1^{\circ} \mathrm{N}-2^{\circ} 30^{\prime} \mathrm{S}$ & +2.52 & +2.0 \\
6-23 Dec 2012 & $\sim 9^{\circ} \mathrm{S}-\sim 16^{\circ} \mathrm{S}$ & -0.68 & -0.2 \\
10-19 Oct 2015 & $\sim 9^{\circ} \mathrm{S}-\sim 16^{\circ} \mathrm{S}$ & +2.52 & +2.1 \\
\hline
\end{tabular}

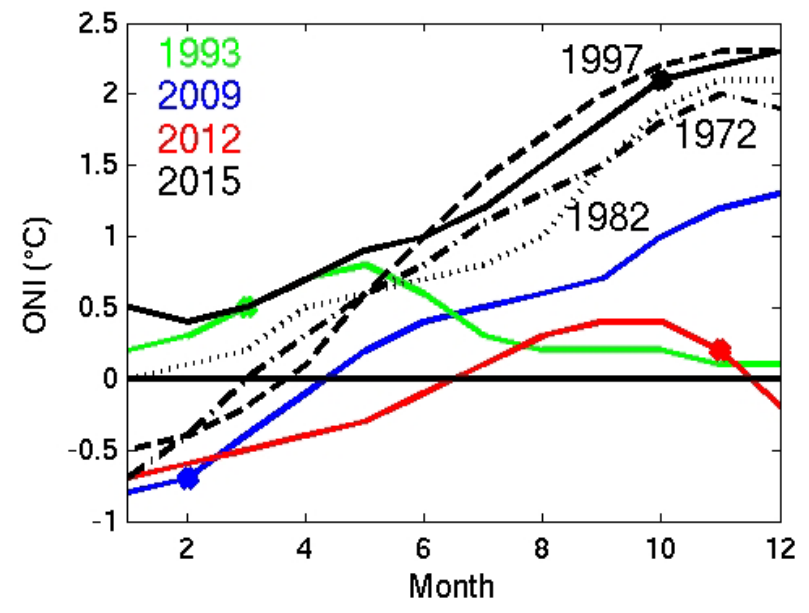

Figure 3. ONI for the strong El Niño years 1972 (dash-dotted), 1982 (dotted), 1997 (dashed), and the years used here: 1993 (green), 2009 (blue), 2012 (red), and 2015 (black line). The months of measurements used here are marked by colored dots.

The only El Niño events since 1950 with an October maximum ONI of more than 1.7, or an overall maximum of 2.0 or larger, are the 1972/73, 1982/83, and 1997/98 El Niños. In early 2015 the ONI was even larger than the ONI of these three large El Niño events, while in October 2015 it was at a similar strength as the three earlier strong El Niños (Fig. 3). Accordingly, the $2015 \mathrm{El}$ Niño has to be listed as one of the four strongest El Niños since 1950.

\section{The equatorial region east of the Galapagos Islands}

\subsection{The hydrographic variability}

\subsubsection{Background information}

The hydrographic distribution in the eastern equatorial Pacific is influenced by a seasonal cycle as well as El Niñorelated cycles. At $110^{\circ} \mathrm{W}$ in the eastern Pacific west of the Galapagos Islands, relationships between zonal velocity, temperature, and salinity in the EUC are all evident in the seasonal cycle. The EUC peaks in strength around April/May, when it also surfaces (Johnson et al., 2002). The thermocline is extremely sharp and shallow. The meridional equatorial spreading of the thermocline associated with the EUC zonal velocity strength is noticeably stronger during April than in October, when in April equatorial SST is lowest and the South Equatorial Current (SEC) is strongest (Johnson et al., 2002). The laterally isolated salinity maximum within the thermocline just south of the Equator is strongest when the EUC velocity is at its greatest (Johnson et al., 2002), and this is also visible in the sea surface salinity (Supplement Fig. S1) from the MIMOC climatology (Schmidtko et al., 2013). Between austral fall and winter the minimal oxygen concentration of the ODZ core in the eastern South Pacific at the Equator changes from 8 to $5 \mu \mathrm{mol} \mathrm{O} \mathrm{O}^{-1}$ (Paulmier and Ruiz-Pino, 2009).

Weaker trade winds during El Niño conditions result in a weaker equatorial circulation, while stronger trade winds during La Niña conditions lead to a stronger equatorial circulation (Johnson et al., 2002). During La Niña, the current system at $110^{\circ} \mathrm{W}$ is spun upwards when compared to El Niño. The cold tongue located in the eastern tropical Pacific is quite weak during El Niño. Surface salinities are generally fresher during El Niño than during La Niña, a feature that is at least partially a product of increased local precipitation associated with the eastward migration of warm sea surface temperatures and convection, and partly a result of the reduced trade winds (Johnson et al., 2002). For the 1996-1998 El Niño-La Niña cycle, a fresh mixed layer in the eastern equatorial Pacific and higher salinity within the pycnocline (defined by the $20^{\circ} \mathrm{C}$ isotherm) during the $\mathrm{El}$ Niño was observed. The higher salinity was caused by the larger equatorward spreading of the subsurface salinity maximum of the South Pacific Tropical Water (SPTW) due to anomalous eastward flow south of the Equator with the relaxation of the South Equatorial Current and the weaker EUC at the Equator (Johnson et al., 2000). Hence, during El Niño events higher salinity should be expected near the pycnocline. 

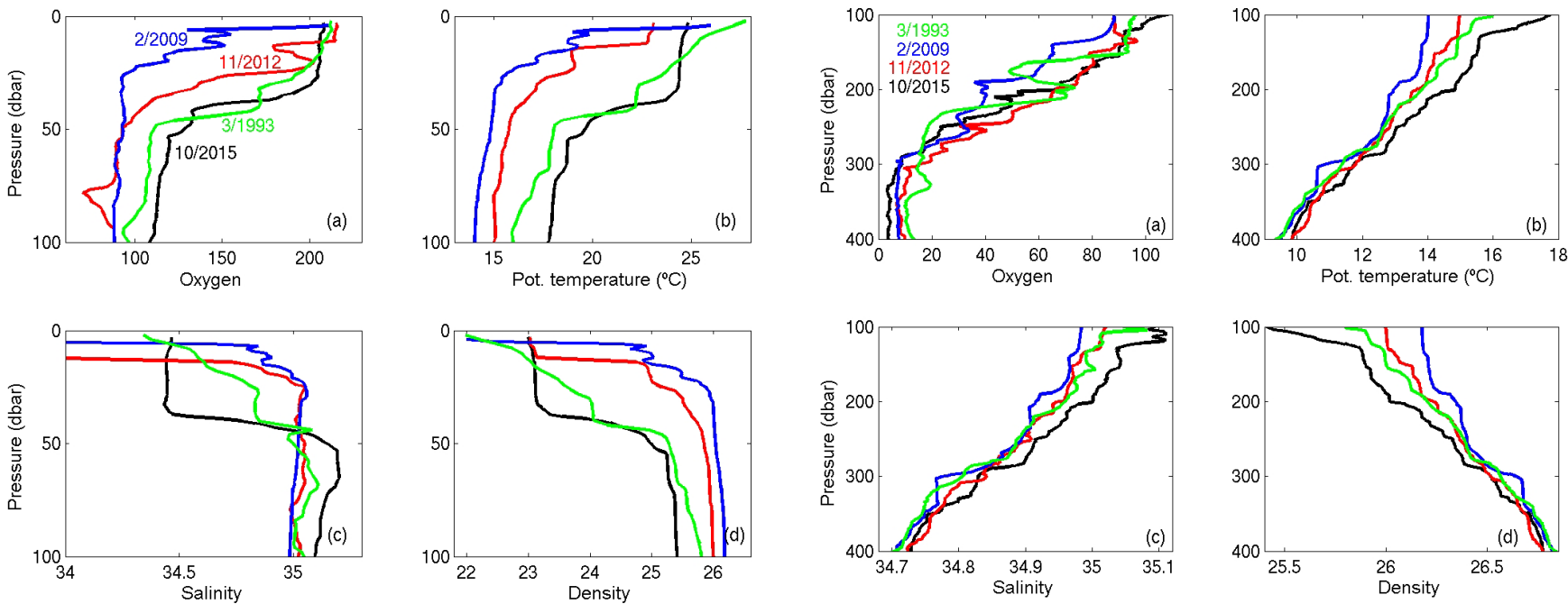

Figure 4. Upper $100 \mathrm{~m}$ profiles at the Equator at $85^{\circ} 50^{\prime} \mathrm{W}$ for 30 March 1993 (green), 12 February 2009 (blue), 2 November 2012 (red), and at the Equator at $85^{\circ} 30^{\prime} \mathrm{W}$ for 7 October 2015 (black) for (a) oxygen in $\mu \mathrm{mol} \mathrm{kg}-1$, (b) potential temperature in ${ }^{\circ} \mathrm{C}$, (c) salinity, and (d) potential density in $\mathrm{kg} \mathrm{m}^{-3}$.

\subsubsection{Observations for the 2015 El Niño}

SST anomalies for the period 27 September to 24 October 2015 showed an SST anomaly of $2.0-2.5^{\circ} \mathrm{C}$ at $85^{\circ} 30^{\prime} \mathrm{W}$ at and south of the Equator, and of $1.5-2.0^{\circ} \mathrm{C}$ just north of the Equator (Fig. 2). In the upper $100 \mathrm{~m}$ of the water column, oxygen, temperature, salinity, and density profiles at the Equator on the $\sim 85^{\circ} 30^{\prime} \mathrm{W}$ meridian (Fig. 4) reveal differences between March 1993, February 2009, November 2012, and the El Niño of October 2015. It is important to note that 1993 was not defined as an official El Niño year as only four, instead of five, consecutive overlapping 3-month periods were at or above the $0.5^{\circ} \mathrm{C}$ anomaly. However, in March and April 1993 the NINO $1+2$ index reached +0.65 and +0.97 (Table 1) and had El Niño-like SST anomalies. To this end, we will refer to March 1993 as 'El Niño-like" hereinafter.

In February 2009 the ONI was for the fourth and last month -0.5 or less; therefore, conditions were similar to a weak La Niña event and we will refer to it as "La Niñalike" hereinafter. In February 2009, in the upper $100 \mathrm{~m}$ at the Equator at $\sim 85^{\circ} 30^{\prime} \mathrm{W}$, the oxygen and temperature were lowest and the density highest compared to the other three periods (Fig. 4), representing an expected La Niña parameter distribution. The hydrographic profiles in the neutral ONI period in November 2012 mainly lay between the El Niño profiles for March 1993 and October 2015, and the La Niñalike profiles in February 2009. The November 2012 profiles were somewhat closer to the February 2009 profiles. The El Niño profiles in October 2015 and the El Niño-like profiles in March 1993 showed slightly higher oxygen concentrations

Figure 5. Same as Fig. 4 but for 100 to $400 \mathrm{~m}$ depth.

and temperature, and lower density in the upper $100 \mathrm{~m}$ in comparison to November 2012 and February 2009 (Fig. 4). In October 2015 the salinity compared to the 3 other years was lowest in a deep thermocline in the upper $40 \mathrm{~m}$, as expected for the surface layer during an El Niño event because of the increased precipitation and reduced equatorial upwelling. In contrast, a weak salinity maximum was located below $40 \mathrm{~m}$, as expected near the pycnocline as saline warm water progresses from the western Pacific eastward during El Niño. In October 2015 the higher temperature, higher salinity, and lower density reached down to $\sim 350 \mathrm{~m}$, while the oxygen profile below $130 \mathrm{~m}$ merges with the profiles from the other measurement periods (Fig. 5).

The strong thermocline/pycnocline of the eastern tropical Pacific is also a strong nutricline. A consistent general pattern is that nitrate and phosphate increase with depth to $\sim 500 \mathrm{~m}$ with a slight maximum at intermediate depths, while silicate continues to increase with depth (Fiedler and Talley, 2006). The vertical distribution of nutrients at the Equator at $\sim 85^{\circ} 30^{\prime} \mathrm{W}$ shows lower nitrate, phosphate, and silicate concentrations in the upper $200 \mathrm{~m}$ in October 2015 as well as in the El Niño-like year 1993 in comparison to the 2009 and 2012 concentrations (Fig. 6). A primary nitrite maximum (PNM) usually occurs in the lower euphotic zone, which results from nitrite excretion by phytoplankton and/or a decoupling of ammonia and nitrite oxidation (i.e., higher rates of ammonia vs. nitrite oxidation; Fiedler and Talley, 2006; Lomas and Lipschultz, 2006). At the Equator in the eastern Pacific nitrite is close to undetectable below $100 \mathrm{~m}$ depth (Fig. 6). In 1993 and 2015, however, the PNM was located $\sim 25 \mathrm{~m}$ deeper and maximum nitrite concentrations were considerably higher. This reflects the deeper pycnocline in El Niño years. The enhanced nitrite concentrations seem to be caused by the northward transport of high nitrite concentration found in the PNM of the SPTW (e.g., Tsuchiya and 

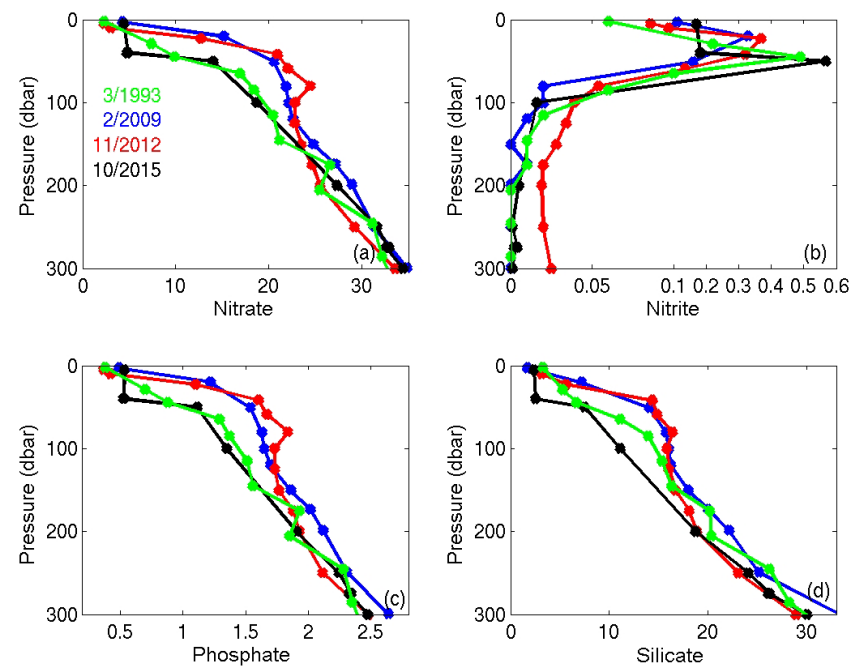

Figure 6. Upper $300 \mathrm{~m}$ profiles at the Equator at $85^{\circ} 50^{\prime} \mathrm{W}$ for 30 March 1993 (green), 12 February 2009 (blue), 2 November 2012 (red), and at the Equator at $85^{\circ} 30^{\prime} \mathrm{W}$ for 7 October 2015 (black) for (a) nitrate in $\mu \mathrm{mol} \mathrm{L}{ }^{-1}$, (b) nitrite in $\mu \mathrm{mol} \mathrm{L}^{-1}$ (scale change at $\left.0.1 \mu \mathrm{mol} \mathrm{L}{ }^{-1}\right)$, (c) phosphate in $\mu \mathrm{mol} \mathrm{L}^{-1}$, and (d) silicate in $\mu \mathrm{mol} \mathrm{L}-1$.

Talley, 1998, and as observed during cruise M90) in combination with a reduced photo inhibition of ammonia oxidation at deeper water depths (see, e.g., Ward, 2008; Grundle et al., 2013). Furthermore, the deep thermocline and pycnocline in October 2015 indicate that equatorial upwelling was reduced. According to the upper ocean hydrographic and nutrient distribution in October 2015, a clear El Niño situation had adjusted at the Equator at $\sim 85^{\circ} 30^{\prime} \mathrm{W}$.

At $1^{\circ} \mathrm{N}, \sim 85^{\circ} 30^{\circ} \mathrm{W}$ in the $50-300 \mathrm{~m}$ layer, salinity and temperature were higher and the density lower in October 2015 than at the other three times; however, the oxygen was not significantly higher during this time (Fig. S2). At $2^{\circ} 30^{\prime} \mathrm{S}$, $\sim 85^{\circ} 30^{\prime} \mathrm{W}$ in the 50 to $250 \mathrm{~m}$ layer, the salinity, temperature, and oxygen were lower and the density higher in the $\mathrm{La}$ Niña-like month of February 2009 than in the other 3 years. The temperature at $2^{\circ} 30^{\prime} \mathrm{S}$ in the El Niño of October 2015 was higher in the 50 to $250 \mathrm{~m}$ depth range than in the other 3 years and salinity showed slightly higher values at $\sim 50$ to 100 and 150 to $250 \mathrm{~m}$ depth. The oxygen concentration was slightly higher only in the upper $\sim 60 \mathrm{~m}$ for both El Niño events in March 1993 and in October 2015 compared to 2009 and 2012 (Fig. S3). However, earlier selected measurements at $4^{\circ} \mathrm{S}, 85^{\circ} \mathrm{W}$ showed a clear oxygen increase to a depth of $\sim 350 \mathrm{~m}$ depth for the El Niño years 1982/83 in comparison to non-El Niño measurements (Czeschel et al., 2012); hence, we conclude that El Niño influence on the water mass distribution was still weak at $2^{\circ} 30^{\prime} \mathrm{S}$ in October 2015 and only developing in the upper ocean.

\subsection{Circulation observations}

\subsubsection{Background information}

The EUC, which carries oxygen-rich water towards the ODZs of the eastern Pacific, has a seasonal cycle, with a transport peak in the eastern Pacific at $95^{\circ} \mathrm{W}$ in April/May of $\sim 30 \mathrm{~Sv}$ and a minimum in October/November of a little less than $15 \mathrm{~Sv}$ (Johnson et al., 2002; their Fig. 17). The Galapagos Islands form a barrier to the EUC, which causes it to bifurcate into a shallow/southern core centered at $\sim 50 \mathrm{~m}$ depth (EUCs) and a deeper/northern core centered at $\sim 150 \mathrm{~m}$ depth (EUCd) (Karnauskas et al., 2010). We are not aware of any El Niño-related EUC variability observations east of the Galapagos Islands. Results from an ocean model for $110^{\circ} \mathrm{W}$ show an increase in the surface eastward EUC current during austral fall, while during other seasons the EUC is at deeper depth (Cravatte et al., 2007). ROMS (Regional Ocean Model System) model results (Montes et al., 2011) for El Niño periods east of the Galapagos Islands show the EUC flowing at a shallower depth associated with lighter water. The model runs display a weakening and southward shift of the EUC branches east of the Galapagos Islands with weaker transports, which are variable, depending on the boundary conditions provided by different ocean general circulation models (OGCMs). The modeled ROMS EUC transports at $86^{\circ} \mathrm{W}$ between $2^{\circ} \mathrm{N}$ and $2^{\circ} \mathrm{S}$ at $200 \mathrm{~m}$ depth for February/March and October/November depending on the OGCMs are $\sim 10-12$ and $\sim 7-8 \mathrm{~Sv}$ for OCCAM, $\sim 6-8$ and $4-5 \mathrm{~Sv}$ for SODA, and $\sim 5.5$ and $7-8 \mathrm{SV}$ for ORCA (Echevin et al., 2011).

During the 1997/98 El Niño shipboard current measurements showed that the EUC virtually disappeared across much of the Pacific basin, associated with the weakening or even the reversal of the equatorial pressure gradient within the pycnocline (Johnson et al., 2000). For the 1982-1983 El Niño there seems to be a strong time delay for the EUC weakening. In September 1982 at $159^{\circ} \mathrm{W}$, the EUC reversed (Firing et al., 1983); however, at $95^{\circ} \mathrm{W}$, the EUC was strong in November 1982 before being replaced by a westward jet in May 1983 (Hayes et al., 1986).

\subsubsection{Observations for the 2015 El Niño}

The direct velocity observations in October 2015 on the diagonal section from the Ecuadorian shelf to $1^{\circ} \mathrm{N}, 85^{\circ} 30^{\prime} \mathrm{W}$, show only a weak signature of the zonal EUC in the upper $100 \mathrm{~m}$ located mainly at, and south, of the Equator (Fig. 7a). The weak transport of the EUC is $0.01 \mathrm{~Sv}$ between $1^{\circ} \mathrm{S}$ and $1^{\circ} \mathrm{N}$, and $0.29 \mathrm{~Sv}$ between $2^{\circ} 30^{\prime} \mathrm{S}$ and $1^{\circ} \mathrm{S}$. The westward flow in the upper $200 \mathrm{~m}$ is mainly connected to a northward flow direction (Fig. 7b) north of $1^{\circ} \mathrm{S}$. This northwesterly flow indicates the flow of oxygen-poor water from the ODZ off the South American continent to the west near the Equator. 

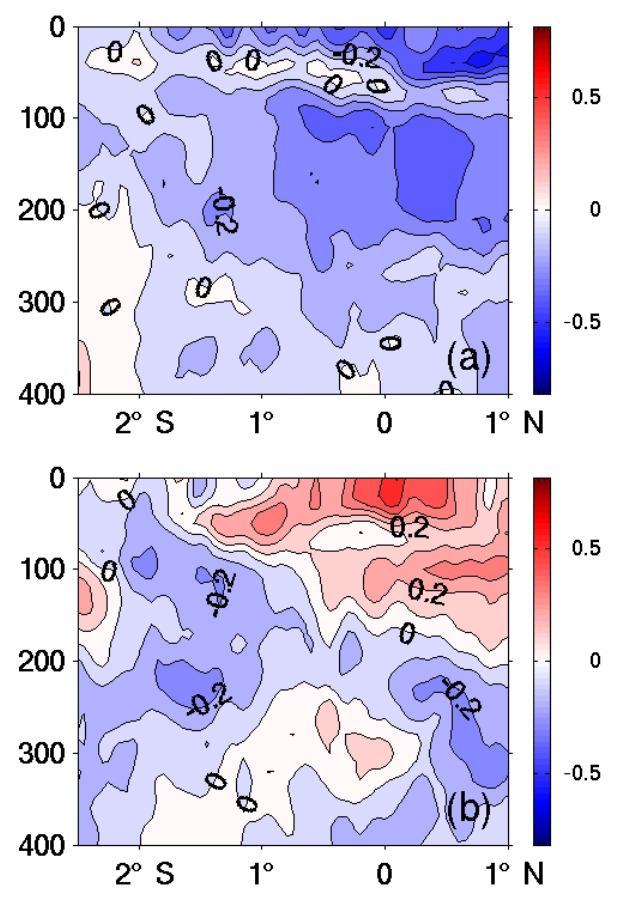

Figure 7. ADCP zonal (positive eastward) (a) and meridional (positive northward) (b) velocity sections (in $\mathrm{m} \mathrm{s}^{-1}$ ) on the diagonal section from the Ecuadorian shelf at $\sim 2^{\circ} 30^{\prime} \mathrm{S}$ to $1^{\circ} \mathrm{N}, 85^{\circ} 30^{\prime} \mathrm{W}$ on 5 and 6 October 2015 (see Fig. 1). The contour interval is $0.1 \mathrm{~m} \mathrm{~s}^{-1}$.

The direct velocity observations on the meridional section at $85^{\circ} 30^{\prime} \mathrm{W}$ between $1^{\circ} \mathrm{N}$ and $2^{\circ} 30^{\prime} \mathrm{S}$ and the diagonal continuation to $5^{\circ} \mathrm{S}, 84^{\circ} 16^{\prime} \mathrm{W}$ again show the weak signature of the EUC in the upper $100 \mathrm{~m}$ located mainly at and south of the Equator north of $2^{\circ} 30^{\prime} \mathrm{S}$ in October 2015 (Fig. 8d). The EUC transport in the upper $300 \mathrm{~m}$ is $0.02 \mathrm{~Sv}$ between $1^{\circ} \mathrm{S}$ and $1^{\circ} \mathrm{N}$ and $0.78 \mathrm{~Sv}$ between $2^{\circ} 30^{\prime} \mathrm{S}$ and $1^{\circ} \mathrm{S}$ (Table 2). The stronger eastward flow component in the upper $200 \mathrm{~m}$ between $3^{\circ} \mathrm{S}$ and $4^{\circ} \mathrm{S}$ might be a combination of the EUC and the Southern Subsurface Countercurrent (SSCC; also called the Tsuchiya Jet), as described for El Niño periods east of the Galapagos Islands in model results (Montes et al., 2011). The eastward flow near $2^{\circ} \mathrm{S}$ below $200 \mathrm{~m}$ is the South Intermediate Countercurrent (SICC).

The strongest EUC in our four measurement periods occurred at the end of March 1993, with $12.77 \mathrm{~Sv}$ between $1^{\circ} \mathrm{S}$ and $1^{\circ} \mathrm{N}$ in the upper $300 \mathrm{~m}$ (Table 2; Fig. 8a). This measurement at the end of March was close to the time of eastern Pacific EUC peak transport in April/May. In addition, it was at the beginning of an El Niño-like phase, where warmer, oxygen-rich water is transported from the western to the eastern tropical Pacific and could enhance the eastward flow component.

In February 2009 the EUC transport between $1^{\circ} \mathrm{S}$ and $1^{\circ} \mathrm{N}$ was weak $(3.55 \mathrm{~Sv})$, although it occurred only 2 months before the time of the seasonal EUC peak transport. As previously described, February 2009 was at the end of a short
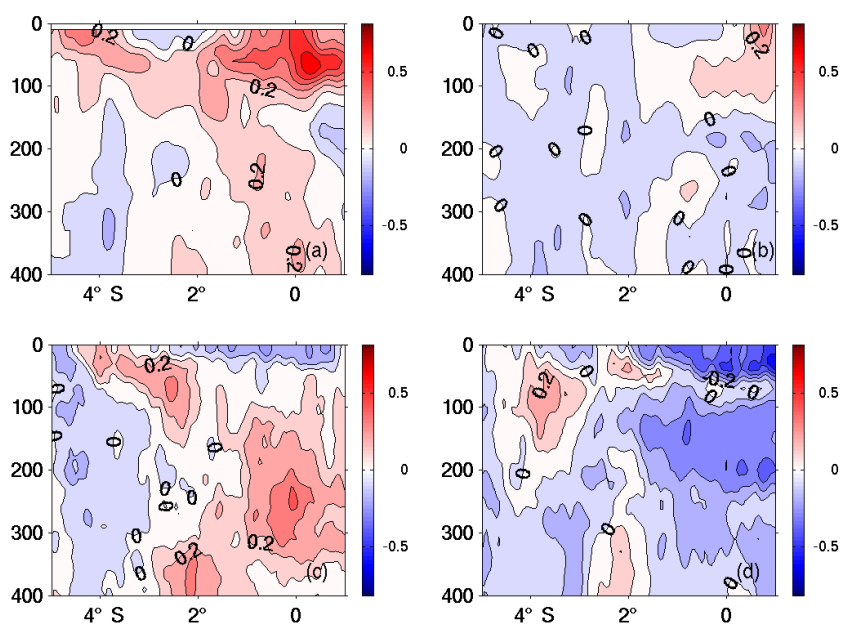

Figure 8. Zonal ADCP velocity sections (in $\mathrm{ms}^{-1}$; positive eastward; contour interval $0.1 \mathrm{~m} \mathrm{~s}^{-1}$ ) on the meridional path from $1^{\circ} \mathrm{N}$ to $5^{\circ} \mathrm{S}$ at $85^{\circ} 50^{\prime} \mathrm{W}$ (a) in March 1993, (b) in February 2009, (c) in November 2012 , and (d) from $1^{\circ} \mathrm{N}$ to $2^{\circ} 30^{\prime} \mathrm{S}$ at $85^{\circ} 30^{\prime} \mathrm{W}$ and diagonal to $5^{\circ} \mathrm{S}, 84^{\circ} 12^{\prime} \mathrm{W}$ in October 2015 (see Fig. 1).

La Niña-like period with an ONI of -0.7 , and the low EUC transport might be related to a generally weak eastward transport of warm western equatorial Pacific water during La Niña. On a cruise approximately 1.5 months later in March to April 2009 between the Galapagos Islands and Ecuador, a region of possible strong cross-hemispheric exchange was observed immediately to the east of the Galapagos Islands, where a shallow $(200 \mathrm{~m}) 300 \mathrm{~km}$ wide northeastward surface flow transported 7 to $11 \mathrm{~Sv}$ (Collins et al., 2013). This northeastward flow might have weakened the EUC transport at and south of the Equator. The two diagonal sections in March/April 2009 crossed the $85^{\circ} 50^{\prime} \mathrm{W}$ section at $\sim 1^{\circ} 50$ and $2^{\circ} 30^{\prime} \mathrm{S}$ and, similarly to the February 2009 measurements, showed a $50 \mathrm{~m}$ depth eastward and westward flow at $1^{\circ} 50$ and $2^{\circ} 30^{\prime} \mathrm{S}$, respectively, and a westward flow at both of these latitudes at $200 \mathrm{~m}$ depth. In contrast to the velocity distribution in March 1993, November 2012, and October 2015 (Fig. 8), the eastward flow component in the upper $200 \mathrm{~m}$ south of $2^{\circ} 30^{\prime} \mathrm{S}$ almost disappeared in February 2009.

The EUC transport in November 2012 at $85^{\circ} 50^{\prime} \mathrm{W}$ between $1^{\circ} \mathrm{S}$ and $1^{\circ} \mathrm{N}$ was $10.78 \mathrm{~Sv}$ in the upper $300 \mathrm{~m}$ (Table 2). The months before these measurements had no large ONI values and should represent the non-El Niño EUC transport in this region for November. The transport of $10.78 \mathrm{~Sv}$ in November at $85^{\circ} 50^{\prime} \mathrm{W}$ is less than the November minimum at $95^{\circ} \mathrm{W}$ of $\sim 15 \mathrm{~Sv}$ (Johnson et al., 2002; their Fig. 17), and seems to be a reasonable estimate east of the Galapagos Islands, as the EUC transport decreases in the eastern Pacific. The core of the EUC below $200 \mathrm{~m}$ is quite deep and agrees with the seasonal cycle where the EUC should be located at deeper depth in austral spring. 
Table 2. Summed zonal positive (eastward) and negative (westward) ADCP transports in Sv $\left(10^{6} \mathrm{~m}^{3} \mathrm{~s}^{-1}\right)$ in the equatorial channel at $85^{\circ} 50^{\prime} \mathrm{W}$ in March 1993, February 2009, and November 2012 and at $85^{\circ} 30^{\prime} \mathrm{W}$ in October 2015 as well as the related El Niño status. The velocity data were slightly smoothed and extrapolated to the surface.

\begin{tabular}{lrrrrl}
\hline Time & $1^{\circ} \mathrm{S}-1^{\circ} \mathrm{N}$ & $0-300 \mathrm{~m}$ & $2^{\circ} 30^{\prime} \mathrm{S}-1^{\circ} \mathrm{S}$ & $0-300 \mathrm{~m}$ & El Niño status \\
\hline 29-31 Mar 1993 & 12.77 & -0.38 & 6.28 & -0.07 & Early El Niño-like \\
12-13 Feb 2009 & 3.55 & -1.58 & 0.55 & -1.57 & Late La Niña-like \\
1-3 Nov 2012 & 10.78 & -0.94 & 4.22 & -0.36 & Neutral \\
7-8 Oct 2015 & 0.02 & -13.86 & 0.78 & -4.08 & El Niño \\
\hline
\end{tabular}

\section{The upwelling region off Peru}

\subsection{Background information}

Off Peru a highly productive year-round upwelling system is located between 4 and $16^{\circ} \mathrm{S}$ (Chavez and Messié, 2009). Since the 1950s, an SST decline corresponding to an increase in upwelling has been observed off Peru (Gutiérrez et al., 2011). The SST off Peru measured at six locations between 5 and $12^{\circ} \mathrm{S}$ over a period of 6 years shows a seasonal cycle of 2 to $3{ }^{\circ} \mathrm{C}$ amplitude with the largest SST near March and the minimum near October (Montes et al., 2011; their Fig. 4). This seasonal cycle is also visible in the MIMOC climatology for 9 and $12^{\circ} 30^{\prime} \mathrm{S}$ (Fig. S1). The time-series station at $\sim 12^{\circ} \mathrm{S}, 77^{\circ} 30^{\prime} \mathrm{W}$ shows a seasonal cycle of about $20 \mathrm{~m}$ displacement for the $15^{\circ} \mathrm{C}$ isotherm, the oxycline depth, and the upper boundary of the ODZ (Graco et al., 2016). Seasonal eddy fluxes are described along the coast of Peru, with the largest signal at approximately $15^{\circ} \mathrm{S}$ with a peak during the austral winter (Vergara et al., 2016). The typical nutrient distribution along a cross-shelf section at $12^{\circ} \mathrm{S}$ (as seen in December 2012) shows elevated phosphate concentrations in the surface waters near the coast, whereas nitrate is depleted in the water column and the near-surface waters close to the coast (Kock et al., 2016; their Fig. 3).

Conditions that develop along the coast of Ecuador, Peru, and northern Chile during El Niño events include a strengthening of the poleward flow along the coast of Peru, persistent deepening of the thermocline, reducing or even reversing the prevailing upwelling-induced land-sea temperature gradient, and a southward shift in the position of the ITCZ (InterTropical Convergence Zone), which brings heavy precipitation to normally arid regions (Strub et al., 1998). A reduction in coastal cloud cover due to warmer water next to the coast may enhance insolation and reduce atmospheric pressure over land, maintaining the pressure difference and winds over the coast. As a result, upwelling-favorable winds are not greatly reduced when El Niño conditions are observed in the ocean (Enfield 1981; Huyer et al., 1987; Strub et al., 1998; Halpern et al., 2002). In general, upwelling-favorable winds and upwelling continue during El Niño events, and water continues to be drawn from 50 to $100 \mathrm{~m}$ depth to the surface layer, but the thermocline and nutricline are displaced downward and thickened, so that upwelling during El Niño brings only warm and nutrient-poor water to the surface (Enfield 1981; Huyer et al., 1987; Strub et al., 1998; Halpern et al., 2002). The intensity of the upwelling appears to be determined by an interplay between along-shore, poleward advection and wind intensity, but also by the cross-shore geostrophic flow and distribution of the water masses on a scale of $1000 \mathrm{~km}$ or more (Colas et al., 2008). In relation to the downward displacement of the thermocline and nutricline, the oxycline is also displaced downward. For the 1997/98 El Niño event, Helly and Levin (2004) described a possible depression of the upper layer of the ODZ (defined by oxygen concentrations $<0.5 \mathrm{mLL}^{-1} ; \sim 22.3 \mu \mathrm{mol} \mathrm{L}^{-1}$ ) by $100 \mathrm{~m}$, reducing the ODZ area off Peru and northern Chile (6-20 $\mathrm{S}$ ) by $61 \%$ (from 77000 to $30000 \mathrm{~km}^{2}$ ).

\subsection{Observations for the $2015 \mathrm{EI}$ Niño}

The SST anomalies for the period 27 September to 24 October 2015 (Fig. 2) showed a strong SST anomaly of $1.5-2.0^{\circ} \mathrm{C}$ between 8 and $14^{\circ} \mathrm{S}$ and a weaker anomaly of $0.5-1.5^{\circ} \mathrm{C}$ between 14 and $20^{\circ} \mathrm{S}$. Differing hydrographic distributions were measured off Peru at $\sim 9^{\circ} \mathrm{S}$ in December 2012 with a neutral ONI status and in October 2015 with the strong El Niño. In the entire upper $300 \mathrm{~m}$ at $\sim 9^{\circ} \mathrm{S}$, temperature, salinity (Figs. S4 and S5), and oxygen (Fig. 9) were higher in October 2015 than in December 2012. In contrast to the typical seasonal cycle that is characterized by lower SST in October than in December, the SST at $9^{\circ} \mathrm{S}$ was higher in October 2015 than in December 2012 as a result of the El Niñorelated SST increase. Higher upper water column temperatures in October 2015 also correlated with lower densities in the upper $300 \mathrm{~m}$ (as can be seen from the selected isopycnals in Fig. 9) despite the concurrent influence on density from the salinity increase. Accordingly the density changes are temperature dominated. In December 2012 there was strong upwelling at $\sim 9^{\circ} \mathrm{S}$ with the $<5 \mu \mathrm{mol} \mathrm{kg}{ }^{-1} \mathrm{O}_{2}$ layer located below $\sim 30 \mathrm{~m}$ depth, while in October 2015 this low oxygen layer was only found below $240 \mathrm{~m}$ depth. The October 2015 nutrient profiles obtained from shelf stations at $\sim 9^{\circ} \mathrm{S}$ with water depths of little more than $100 \mathrm{~m}$ (not shown) highlight the fact that nitrate, phosphate, and silicate concentrations were lower, and nitrite concentrations were higher in comparison to profiles from the same location in December 2012, as 

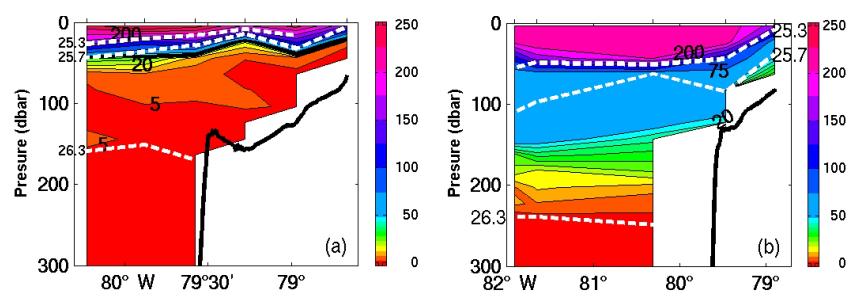

Figure 9. Oxygen section (color; in $\mu \mathrm{mol} \mathrm{kg}{ }^{-1}$; same color scale in both frames) at $\sim 9^{\circ} \mathrm{S}$ off the Peruvian shelf for December 2012 (a) and October 2015 (b). Three selected isopycnals are included as white dashed lines. Please note that the section in October 2015 reaches further west than in December 2012.

would be expected for El Niño periods. Although the isopycnals and parameter distribution show that upwelling at $9^{\circ} \mathrm{S}$ was occurring in October 2015, it is clear that warmer, saline, and oxygen-replete water was being upwelled, and that the contribution of oxygen-depleted and nutrient-rich water was strongly reduced.

At $\sim 12^{\circ} \mathrm{S}$ the measured oxygen distributions for December 2012 and October 2015 are quite similar in the upwelling region at the easternmost station pair with oxygen concentrations of less than $5 \mu \mathrm{mol} \mathrm{kg}{ }^{-1}$ (Fig. 10). The oxygen concentration between the isopycnals $\sigma_{\theta}=25.6$ and $25.8 \mathrm{~kg} \mathrm{~m}^{-3}$ was even lower in October 2015 than in December 2012 in the upwelling region east of $\sim 77^{\circ} 30^{\prime} \mathrm{W}$ (Fig. 10). However, below the oxycline below $50 \mathrm{~m}$ depth, temperature, salinity, and oxygen concentrations (Fig. 11f) were higher in October 2015 than in December 2012 and indicate the transition to El Niño conditions. The seasonal signal in the time-series station at $\sim 12^{\circ} \mathrm{S}, 77^{\circ} 30^{\prime} \mathrm{W}$ shows a shallower $15^{\circ} \mathrm{C}$ isotherm and oxycline depth of about $20 \mathrm{~m}$ in October than in December (Graco et al., 2016); hence, the deeper oxycline in October 2015 compared to December 2012 is not a seasonal signal but an El Niño influence. The nutrient distribution at the shelf at $\sim 12^{\circ} \mathrm{S}$ (Fig. 11) also shows El Niño influence with lower phosphate and silicate in October 2015 than in December 2012. This is in agreement with the observed increase in temperature and salinity, and the lower phosphate and silicate at the time-series station at $\sim 12^{\circ} \mathrm{S}$ during the strong 1997/1998 El Niño (Graco et al., 2016). Under El Niño conditions upwelling is reduced and this prevents nutrients such as phosphate and silicate from becoming enriched in the mixed layer. Nitrate and nitrite are different, however, because their distributions are driven more by oxygen availability, which regulates nitrification and denitrification. Indeed, nitrate was lower and nitrite was higher in December 2012 than in October 2015, with nitrite reaching $5.4 \mu \mathrm{mol} \mathrm{L}^{-1}$ at $75 \mathrm{~m}$ in December 2012 (Fig. 11), consistent with the observations of Kock et al. (2016). At the depths of the high nitrite concentrations in December 2012, very low oxygen concentrations of less than $2 \mu \mathrm{mol} \mathrm{kg}{ }^{-1}$ were measured. Under low oxygen conditions, incomplete nitrification, incomplete denitrification, or a combination of both, can result in accumula-
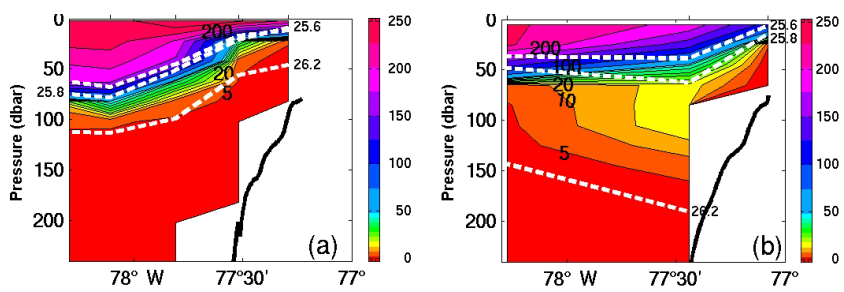

Figure 10. Oxygen section (color; in $\mu \mathrm{mol} \mathrm{kg}{ }^{-1}$; same color scale in both frames) at $\sim 12^{\circ} \mathrm{S}$ off the Peruvian shelf for December 2012 (a) and October 2015 (b). Three selected isopycnals are included as white dashed lines.
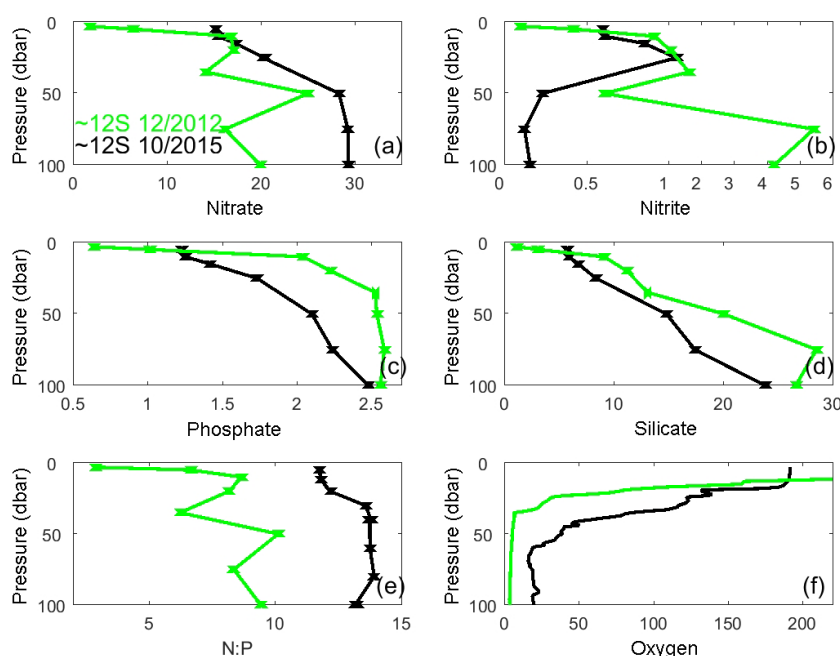

Figure 11. Nutrient profiles at shelf stations with water depth of slightly more than $100 \mathrm{~m}$ in December 2012 at $12^{\circ} 15^{\prime} \mathrm{S}, 77^{\circ} 31^{\prime} \mathrm{W}$ (green) and in October 2015 at $12^{\circ} 21^{\prime} \mathrm{S}, 77^{\circ} 25^{\prime} \mathrm{W}$ (black) for (a) nitrate in $\mu \mathrm{mol} \mathrm{L} \mathrm{L}^{-1}$, (b) nitrite in $\mu \mathrm{mol} \mathrm{L}{ }^{-1}$, (scale change at $1 \mu \mathrm{mol} \mathrm{L}-1)$, (c) phosphate in $\mu \mathrm{mol} \mathrm{L}-1$, (d) silicate in $\mu \mathrm{mol} \mathrm{L}-1$, (e) $\mathrm{N}: \mathrm{P}$ ratio, and (f) CTD oxygen in $\mu \mathrm{mol} \mathrm{kg}-1$.

tions of nitrite (e.g., Codispoti and Christensen, 1985; Gruber, 2008; Brockmann and Morgenroth, 2010), as was likely the case during 2012. The higher oxygen concentrations in the ODZ at $\sim 12^{\circ} \mathrm{S}$ during October 2015 would have prevented the build-up of nitrite, as under these conditions denitrification shuts off and nitrification goes to completion, producing more nitrate.

Another notable difference between December 2012 and October 2015 at $\sim 12^{\circ} \mathrm{S}$ is the lower $\mathrm{N}: \mathrm{P}$ ratios in the upper $150 \mathrm{~m}$ during 2012 vs. 2015 (Fig. S6e). Again, higher oxygen concentrations in the upper $150 \mathrm{~m}$ during the $2015 \mathrm{El}$ Niño probably reduced the impact of fixed $\mathrm{N}$ loss processes on the $\mathrm{N}: \mathrm{P}$ signatures of near-surface waters. These results imply that El Niño conditions could, at least, partially alleviate phytoplankton $\mathrm{N}$ limitation due to the reduction in the magnitude of denitrification. While it is beyond the scope of the focus of this study, it would be interesting to examine whether this increase in $\mathrm{N}: \mathrm{P}$ ratios during the $2015 \mathrm{El}$ 
Niño impacted the phytoplankton communities within this region. The expectation that they may have impacted the phytoplankton communities is certainly reasonable (Rousseaux and Gregg, 2012), as Hauss et al. (2012) observed an increase in diatom biomass when the $\mathrm{NO}_{3}^{-}: \mathrm{PO}_{4}^{3-}$ ratios of water collected from the Peruvian upwelling region were increased.

The results from $\sim 12^{\circ} \mathrm{S}$ shelf water indicate that upwelling of oxygen-poor water was still continuing in October 2015 at $12^{\circ} \mathrm{S}$ in the near-surface layer, despite the enhanced SST anomaly related to El Niño. Below the oxycline, however, El Niño conditions were developing. The observations west of $77^{\circ} 48^{\prime} \mathrm{W}$ in the upper $75 \mathrm{~m}$ show that oxygen as well as temperature (not shown) were lower in October 2015, maybe related to a stronger poleward flow of the Peru-Chile Undercurrent (PCUC), which has been shown to be a characteristic of El Niño events (Strub et al., 1998). The PCUC advects seawater property anomalies from equatorial to extratropical regions and shoals during El Niño despite the velocity and transport intensification (Montes et al. 2011; Chaigneau et al., 2013).

At $\sim 14^{\circ} \mathrm{S}$ at the easternmost station near the shelf, the oxygen distribution is quite similar for December 2012 and October 2015 (Fig. S6), indicating non-El Niño oxygen-poor upwelling near the shelf. West of $77^{\circ} \mathrm{W}$, the isopycnals are deeper in October 2015, related to a deeper thermocline with warmer water in the upper $100 \mathrm{~m}$ (not shown) and higher oxygen in October 2015 compared to December 2012. Similar to $\sim 12^{\circ} \mathrm{S}$ the nutrient distribution shows higher nitrate and lower phosphate and silicate in October 2015 compared to December 2012 at $\sim 14^{\circ} \mathrm{S}$. As outlined above, the higher nitrate concentrations in October 2015 likely result from less denitrification and more complete nitrication, as a result of the increased oxygen concentrations, and this again provides evidence of a developing El Niño situation.

At $\sim 16^{\circ} \mathrm{S}$ the oxygen concentrations at the shelf were lower in October 2015 than in December 2012 (Fig. S7), indicating similarity to $\sim 14^{\circ} \mathrm{S}$ non-El Niño upwelling close to the shelf. The higher oxygen near the shelf in December 2012 was probably related to an unusual distribution related to an eddy located near the $\sim 16^{\circ} \mathrm{S}$ section (e.g., Stramma et al., 2013; Czeschel et al., 2015). The SST at $\sim 14$ and $\sim 16^{\circ} \mathrm{S}$ was lower in October 2015 than in December 2012; hence, the slight increase in SST by El Niño did not compensate for the typical seasonal SST signal. Different to the sections at $\sim 9^{\circ} \mathrm{S}, \sim 12$, and $\sim 14^{\circ} \mathrm{S}$, at $\sim 16^{\circ} \mathrm{S}$ the density distribution below the thermocline did not shift to higher densities in October 2015, which shows that the El Niño influence at $16^{\circ} \mathrm{S}$ was the weakest of the four shelf sections. The observed transitional feature of normal conditions near-shore and El Niño conditions offshore is probably a consequence of the crossshore pattern in vertical velocity during upwelling. The nearshore vertical velocity is expected to be substantially larger than the offshore vertical velocity (Fennel, 1999). A downwelling Kelvin wave could then neutralize the weak offshore upwelling and bring down the thermocline, while near-shore the strong upwelling would hardly weaken and for some time still bring up remnants of cold oxygen-poor water, until supplies feed from the offshore warmer and oxygen-replete waters. The wind field would not need to change in order to produce this transition pattern in hydrography.

\section{Conclusions}

In this study, hydrographic measurements from a cruise to the eastern tropical Pacific in October 2015 were used to investigate the signal of the strong $2015 \mathrm{El}$ Niño in the water mass distribution and in the EUC in comparison to measurements from the years 1993, 2009, and 2012. An increase in temperature from the surface to $350 \mathrm{~m}$ depth, and salinity in the 40 to $350 \mathrm{~m}$ depth layer, appeared at the Equator east of the Galapagos Islands at $85^{\circ} 30^{\prime} \mathrm{W}$ in October 2015. The warmer temperature led to lower densities despite the concurrent influence of the salinity increase on density. In October 2015, nitrate, phosphate, and silicate concentrations were all lower in the upper $200 \mathrm{~m}$ when compared with previous non-El Niño periods; however, higher oxygen concentrations, which are characteristic of El Niño events, were only located between 40 and $130 \mathrm{~m}$ at the Equator. Except for an oxygen increase in the upper $\sim 60 \mathrm{~m}$ at $2^{\circ} 30^{\prime} \mathrm{S}$, no obvious large vertical oxygen increase appeared at $1^{\circ} \mathrm{N}$ and $2^{\circ} 30^{\prime} \mathrm{S}$ at $85^{\circ} 30^{\prime} \mathrm{W}$. This weak oxygen increase at and near the Equator might be related to the weak EUC, which would otherwise be expected to bring oxygen-richer water eastwards.

Due to the influence of seasonal and El Niño signals, the velocity and transport observations of the EUC east of the Galapagos Islands were quite variable in the direct velocity measurements in different years. In addition, intraseasonal signals with the passage of upwelling and downwelling waves at intraseasonal timescales (Cravatte et al., 2003; Echevin et al., 2014) might modify the measurements. As previously observed in the central and western Pacific, and as predicted from model simulations, the EUC at the Equator almost disappeared, with a transport of only $0.02 \mathrm{~Sv}$ between $1^{\circ} \mathrm{S}$ and $1^{\circ} \mathrm{N}$ in October 2015 related to the El Niño conditions. Although weak, the EUC had shifted southward, with a transport of $0.78 \mathrm{~Sv}$ between $2^{\circ} 30^{\prime}$ and $1^{\circ} \mathrm{S}$ in October 2015. These observations are in agreement with the predicted weakening and southward shift of the EUC in model results for El Niño periods (Montes et al., 2011). According to earlier observations, the disappearance of the EUC in the eastern Pacific seems to be related mainly to strong El Niño events. For the very strong 1982/83 El Niño, a disappearance of the EUC was described for the eastern Pacific (Halpern, 1997), whereas for the strong 1997/98 El Niño the EUC disappeared over all longitudes (Izumo, 2005). In contrast, during the moderate El Niños of 1986/87 and 1991/92 a disappearance was described in the western and central Pacific, but only a weakening in the eastern Pacific (McPhaden et al., 
1990; McPhaden and Hayes, 1990; Izumo, 2005; Kessler and McPhaden, 1995; Seidel and Giese, 1999).

Four hydrographic sections near the Peruvian shelf between $\sim 9$ and $\sim 16^{\circ} \mathrm{S}$ had different El Niño related signals in October 2015. At $\sim 9^{\circ} \mathrm{S}$ there was a large SST increase, and we observed upwelling of lighter water that was both warmer and more oxygenated, all of which are characteristic upwelling features of El Niño events. Between 12 and $16^{\circ} \mathrm{S}$ the SST increase in October 2015 was weaker than at $9^{\circ} \mathrm{S}$, and at the easternmost stations near the Peruvian shelf at $\sim 12, \sim 14$ and $\sim 16^{\circ} \mathrm{S}$ cold and oxygen-poor water was upwelled as during regular upwelling conditions, probably some leftover water from the pre-El Niño period. West of the easternmost stations, El Niño type changes were also observed below the thermocline and oxycline, a feature that weakened southward and that may be related to the shoaling and intensification of the PCUC and the influence of a downwelling Kelvin wave.

The 2015 El Niño started strongly early in the year, and by October 2015 had an ONI similar to earlier major El Niño events. The water characteristics at $85^{\circ} 30^{\prime} \mathrm{W}$ at the Equator and EUC variability and upwelling at $\sim 9^{\circ} \mathrm{S}$ also indicated that a strong EP El Niño had developed. However, at $1^{\circ} \mathrm{N}$ and $2^{\circ} 30^{\prime} \mathrm{S}$ at $85^{\circ} 30^{\prime} \mathrm{W}$ and at the sections near the shelf between 12 and $16^{\circ} \mathrm{S}$, the El Niño influence was still weak. To this end, the weak EUC clearly indicated a strong EP El Niño at the Equator, while off the South American continent the distribution of hydrographic parameters, oxygen, and nutrients indicated a transition period from regular to El Niño conditions progressing southward along the Peruvian shelf. Despite the strong $2015 \mathrm{El}$ Niño, the shift to El Niño distribution in the eastern Pacific was surprisingly slow. As the ONI increased to the end of 2015, we expect that the El Niño conditions were strengthening in the eastern Pacific after the cruise in October 2015. Measurements carried out by CNRS, IRD, and IMARPE with a glider from IFREMER at about $8^{\circ} \mathrm{S}$ off Peru between 7 November and 17 December 2015 showed an increase in temperature and oxygen and a decrease in density at $\sim 100 \mathrm{~m}$ when compared to October 2015 , thus confirming the expected strengthening of the El Niño conditions (https://www.ird.fr/toutel-actualite/actualites/).

In summary, the temperature, salinity, and oxygen measurements all indicate that during October 2015 the El Niño was strongest along our northern transects and weakest along our southern transects. This was also apparent in the nutrient properties between the northern and southern portions of our study region. As outlined above, at $12^{\circ} \mathrm{S}$ the $\mathrm{N}$ : $\mathrm{P}$ ratio was higher and nitrite concentrations were lower during October 2015 when compared to the non-El Niño period of December 2012, both of which point to a reduction in the magnitude of denitrification. When comparing the differences between coastal nutricline $\mathrm{N}: \mathrm{P}$ ratios and nitrite concentrations along the coast, we found that the differences between October 2015 and December 2012 decreased between 12 and $14^{\circ} \mathrm{S}$, and again between 14 and $16^{\circ} \mathrm{S}$ (data not shown). This again highlights the potential for El Niño events to impact $\mathrm{N}$ loss processes and upper water column biogeochemistry.

\section{Data availability}

The data from the R/V Knorr cruise in March/April 1993 are available for ADCP at ftp://ftp.soest.hawaii.edu/caldwell/ adcp/DATABASE/00015.html, for CTD data as https://doi. pangaea.de/10.1594/PANGAEA.294039, and for nutrients as https://doi.pangaea.de/10.1594/PANGAEA.837024. The assembled measurements of the Meteor cruises in February 2009, November 2012, and December 2012 and the Sonne cruise in October 2015 used in this paper are available at https://doi.pangaea.de/10.1594/PANGAEA.861392.

\section{The Supplement related to this article is available online at doi:10.5194/os-12-861-2016-supplement.}

Author contributions. Lothar Stramma and Tim Fischer conceived the study, wrote the manuscript, and carried out the ADCP and hydrographic measurements on the R/V Sonne cruise in 2015 as well as on some of the R/V Meteor cruises. Damian S. Grundle was cochief scientist of the R/V Sonne cruise in October 2015, organized the nutrient sampling, and interpreted the nutrient data. Gerd Krahmann calibrated the R/V Meteor and R/V Sonne CTD data and interpreted the hydrographic data. Hermann W. Bange was chief scientist on R/V Meteor in December 2012, he was responsible for the nutrient measurements on this cruise and interpreted the nutrient data. Christa A. Marandino was chief scientist on the R/V Sonne cruise in October 2015 and interpreted the nutrient data. All authors discussed and modified the manuscript.

Acknowledgements. The Deutsche Forschungsgemeinschaft (DFG) provided support as part of Sonderforschungsbereich 754: Climate-Biogeochemistry Interactions in the Tropical Ocean and for the $\mathrm{R} / \mathrm{V}$ Meteor cruises. The Bundesministerium für Bildung und Forschung (BMBF) supported this study as part of the SOPRAN project (03F0611A, 03F0662A) and through funding of the R/V Sonne cruise in October 2015 (03G0243A). We thank the captains and crews of the R/V Meteor and R/V Sonne cruises for their help, R. Czeschel for helpful comments on the graphic software, T. Steinhoff for co-organizing the R/V Sonne cruise, and M. Lohmann and H. Campen for the oxygen and nutrient measurements.

Edited by: M. Hoppema 


\section{References}

Ashok, K. and Yamagata, T.: The El Niño with a difference, Nature, 461, 481-484, 2009.

Bange, H. W.: Surface Ocean - Lower Atmosphere Study (SOLAS) in the upwelling region off Peru - Meteor Cruise No M91, Meteor Berichte, Bremerhaven, 69 pp., 2013.

Brockmann, D. and Morgenroth, E.: Evaluating operating conditions for out-competing nitrite oxidizers and maintaining partial nitrification in biofilm systems using biofilm modeling and Monte Carlo filtering, Water Res., 44, 1995-2009, 2010.

Cai, W., Borlace, S., Lengaigne, M., van Rensch, P., Collins, M., Vecchi, G., Timmermann, A., Santoso, A., McPhaden, M. J., Wu, L., England, M. H., Wang, G., Guilyardi, E., and Jin, F.-F.: Increasing frequency of extreme El Niño events due to greenhouse warming, Nature Climate Change, 4, 111-116, 2014.

Chaigneau, A., Dominguez, N., Eldin, G., Vasquez, L., Flores, R., Grados, C., and Echevin, V.: Near-coastal circulation in the Northern Humboldt Current system from shipboard ADCP data, J. Geophys. Res., 118, 5251-5266, 2013.

Changnon, S. A.: El Niño 1997-1998: the climate event of the century, Oxford University Press, New York, ISBN 019-513552-0, 2000.

Chavez, F. P. and Messié, M.: A comparison of eastern boundary upwelling ecosystems, Prog. Oceanogr., 83, 80-96, 2009.

Colas, F., Capet, X., McWilliams, J. C., and Shchepetkin, A.: 19871998 El Niño off Peru: A numerical study, Prog. Oceanogr., 79, 138-155, 2008.

Collins, C., Mascarenhas, A., and Martinez, R.: Structure of ocean circulation between Galapagos Islands and Ecuador, Adv. Geosci., 33, 3-12, 2013.

Codispoti, L. A. and Christensen, J. P.: Nitrification, denitrification, and nitrous oxide cycling in the eastern tropical South Pacific Ocean, Mar. Chem. 16, 277-300, 1985.

Cravatte, S., Picaut, J., and Eldin, G.: Second and first baroclinic Kelvin modes in the equatorial Pacific at intraseasonal timescales, J. Geophys. Res., 108, 3266, doi:10.1029/2002JC001511, 2003.

Cravatte, S., Madec, G., Izumo, T., Menkes, C., and Bozec, A.: Progress in the 3-D circulation of the eastern equatorial Pacific in a climate model, Ocean Model., 17, 28-48, doi:10.1016/j.ocemod.2006.11.003, 2007.

Czeschel, R., Stramma, L., Schwarzkopf, F. U., Giese, B. J., Funk, A., and Karstensen, J.: Middepth circulation of the eastern tropical South Pacific and its link to the oxygen minimum zone, J. Geophys. Res., 116, C01015, doi:10.1029/2010JC006565, 2011.

Czeschel, R., Stramma, L., and Johnson, G. C.: Oxygen decreases and variability in the eastern equatorial Pacific, J. Geophys. Res., 117, C11019, doi:10.1029/2012JC008043, 2012.

Czeschel, R., Stramma, L., Weller, R. A., and Fischer, T.: Circulation, eddies, oxygen, and nutrient changes in the eastern tropical South Pacific Ocean, Ocean Sci., 11, 455-470, doi:10.5194/os11-455-2015, 2015.

Dewitte, B., Vazquez-Cuervo, J., Goubanova, K., Illig, S., Takahashi, K., Cambon, G., Purca, S., Correa, D., Gutierrez, D., Sifeddine, A., and Ortlieb, L.: Change in El Niño flavours over 1958-2008: Implications for the long-term trend of the upwelling off Peru, Deep-Sea Res. Pt. II, 77-80, 143-156, 2012.

Echevin, V., Colas, F., Chaigneau, A., and Penven, P.: Sensitivity of the Northern Humboldt Current System nearshore modelled circulation to initial boundary conditions, J. Geophys. Res., 116, C07002, doi:10.1029/2010JC006684, 2011.

Echevin, V., Albert, A., Lévy, M., Graco, M., Aumont, O., Piétri, A., and Garric, G.: Intraseasonal variability of nearshore productivity in the Northern Humboldt current system: The role of coastal trapped waves, Cont. Shelf Res., 73, 14-30, 2014.

Enfield, D. B.: Thermally driven wind variability in the planetary boundary layer above Lima, Peru, J. Geophys. Res., 86, 20052016, 1981.

Fennel, W.: Theory of the Benguela upwelling system, J. Phys. Oceanogr., 29, 177-190, 1999.

Fiedler, P. C. and Talley, L. D.: Hydrography of the eastern tropical Pacific: A review, Prog. Oceanogr., 69, 143-180, 2006.

Firing, E., Lukas, R., Sadler, J., and Wyrtki, K.: Equatorial Undercurrent disappears during 1982-1983 El Niño, Science, 222, 1121-1123, 1983.

Fuenzalida, P., Schneider, W., Garces-Vargas, J., Bravo, L., and Lange, C.: Vertical and horizontal extension of the oxygen minimum zone in the eastern South Pacific Ocean, Deep-Sea Res., Pt. II, 56, 992-1003, 2009.

Graco, M., Purca, S., Dewitte, B., Morón, O., Ledesma, J., Flores, G., Castro, C., and Gutiérrez, D.: The OMZ and nutrients features as a signature of interannual and low frequency variability off the peruvian upwelling system, Biogeosciences Discuss., doi:10.5194/bg-2015-567, in review, 2016.

Gruber, N.: The marine nitrogen cycle: overview and challenges, in: Nitrogen in the Marine Environment, edited by: Capone, D. G., Bronk, D. A., Mulholland, M. R., and Carpenter, E. J., Academic Press, Burlington, MA, 1-50, 2008.

Grundle, D. S., Juniper, S. K., and Giesbrecht, K. E.: Euphotic zone nitrification in the NE subarctic Pacific: Implications for measurements of new production, Mar. Chem., 155, 113-123, 2013.

Gutiérrez, D., Enríquez, E., Purca, S., Quipúzcoa, L., Marquina, R., Flores, G., and Graco, M.: Oxygenation episodes on the continental shelf of central Peru: Remote forcing and benthic ecosystem response, Prog. Oceanogr., 79, 177-189, 2008.

Gutiérrez, D., Bouloubassi, I., Sifeddine, A., Purca, S., Goubanova, K., Graco, M., Field, D., Méjanelle, L., Velazco, F., Lorre, A., Salvatteci, R., Quispe, D., Vargas, G., Dewitte, B., and Ortlieb, L.: Coastal cooling and increased productivity in the main upwelling zone off Peru since the mid-twentieth century, Geophys. Res. Lett., 38, L07603, doi:10.1029/2010GL046324, 2011.

Halpern, D.: Observations of annual and El Nino flow variations at $0^{\circ}, 110^{\circ} \mathrm{W}$ and $0^{\circ}, 95^{\circ} \mathrm{W}$ during $1980-85$, J. Geophys. Res., 92, 8197-8212, 1987.

Halpern, D.: Offshore Ekman transport and Ekman pumping off Peru during the 1997-1998 El Niño, Geophys. Res. Lett., 29, 1075, doi:10.1029/2001GL014097, 2002.

Hansen, H. P.: Determination of oxygen, in: Methods of Seawater analysis, edited by: Grasshoff, K. K. and Ehrhardt, M., WileyVCH, Weinheim, Germany, 75-89, 1999.

Hauss, H., Franz, J., and Sommer, U.: Changes in N : P stoichiometry influence taxonomic composition and nutritional quality of phytoplankton in the Peruvian upwelling, J. Sea Res., 73, 74-85, 2012.

Hayes, S. P., Mangum, L. J., Barber, R. T., Huyer, A., and Smith, R. L.: Hydrographic variability west of the Galapagos Islands during the 1982-83 El Niño, Prog. Oceanogr., 17, 137-162, 1986. 
Helly, J. J. and Levin, L. A.: Global distribution of naturally occurring marine hypoxia on continental margins, Deep-Sea Res. Pt. I, 51, 1159-1168, 2004.

Huyer, A., Smith, R. L., and Paluszkiewicz, T.: Coastal upwelling off Peru during normal and El Niño times, 1981-1984, J. Geophys. Res., 92, 14297-14307, 1987.

Izumo, T.: The equatorial undercurrent, meridional overturning circulation, and their roles in mass and heat exchanges during El Nino events in the tropical Pacific ocean, Ocean Dynam., 55, $110-123,2005$.

Johnson, G. C., McPhaden, M. J., Rowe, G. D., and McTaggert, K. E.: Upper equatorial Pacific Ocean current and salinity variability during the 1996-1998 El Niño-La Niña cycle, J. Geophys. Res., 105, 1037-1053, 2000.

Johnson, G. C., Sloyan, B. M., Kessler, W. S., and McTaggert, K. E.: Direct measurements of upper ocean currents and water mass properties across the tropical Pacific during the 1990s, Prog. Oceanogr., 52, 31-61, 2002.

Kalvelage, T., Lavik, G., Lam, P., Contreras, S., Arteaga, L., Löscher, C. R., Oschlies, A., Paulmier, A., Stramma, L., and Kuypers, M. M. M.: Nitrogen cycling driven by organic matter export in the South Pacific oxygen minimum zone, Nat. Geosci., 6, 228-234, doi:10.1038/NGEO1739, 2013.

Karnauskas, K. B., Murtugudde, R., and Busalacchi, J.: Observing the Galapagos-EUC interaction: Insights and challenges, J. Phys. Oceanogr., 40, 2768-2777, 2010.

Karstensen, J., Stramma, L., and Visbeck, M.: Oxygen minimum zones in the eastern tropical Atlantic and Pacific oceans, Prog. Oceanogr., 77, 331-350, 2008.

Kessler, W. S.: The circulation of the eastern tropical Pacific: A review, Prog. Oceanogr., 69, 181-217, 2006.

Kessler, W. S. and McPhaden, M. J.: The 1991-1993 El Niño in the central Pacific, Deep-Sea Res. Pt. II, 42, 295-333, 1995.

Kintisch, E.: "The Blob" invades Pacific, flummoxing climate experts, Science, 348, 17-18, 2015.

Kock, A., Arévalo-Martínez, D. L., Löscher, C., and Bange, H. W.: Extreme $\mathrm{N}_{2} \mathrm{O}$ accumulation in the coastal oxygen minimum zone off Peru, Biogeosciences, 13, 827-840, doi:10.5194/bg-13-8272016, 2016.

Lomas, M. W. and Lipschultz, F.: Forming the primary nitrite maximum: Nitrifiers or phytoplankton?, Limnol. Oceanogr., 51, 2453-2467, 2006.

McPhaden, M. J. and Hayes; S. P.: Variability in the eastern equatorial Pacific during 1986-1988, J. Geophys. Res., 95, 1319513208, 1990.

McPhaden, M. J., Hayes, S. P., Mangum, L. J., and Toole, J. M.: Variability in the western equatorial Pacific during the 1986-87 El Nino-Southern Oscillation event, J. Phys. Oceanogr., 20, 190208, 1990

McPhaden, M. J., Zebiak, S. E., and Glantz, M. H.: ENSO as an Integrating Concept in Earth Science, Science, 314, 1740-1745, 2006.

Montes, I., Schneider, W., Colas, F., Blanke, B., and Echevin, V.: Subsurface connections in the eastern tropical Pacific during $\mathrm{La}$ Niña 1999-2001 and El Niño 2002-2003, J. Geophys. Res., 116, C12022, doi:10.1029/2011JC007624, 2011.
Paulmier, A. and Ruiz-Pino, D.: Oxygen minimum zones (OMZs) in the modern ocean, Prog. Oceanogr., 80, 113-128, 2009.

Pennington, J. T., Mahoney, K. L. Kuwahara, V. S., Kolber, D. D., Calienes, R., and Chavez, F. P.: Primary production in the eastern tropical Pacific: A review, Prog. Oceanogr., 69, 285-317, 2006.

Rousseaux, C. S. and Gregg, W. W.: Climate variability and phytoplankton composition in the Pacific Ocean, J. Geophys. Res., 117, C10006, doi:10.1029/2012JC008083, 2012.

Schmidtko, S., Johnson, G. C., and Lyman, J. M.: MIMOC: A global monthly isopycnal upper-ocean climatology with mixed layers, J. Geophys. Res., 118, 1658-1672, doi:10.1002/jgrc.20122, 2013.

Seidel, H. F. and Giese, B. S.: Equatorial currents in the Pacific Ocean 1992-1997, J. Geophys. Res., 104, 7849-7863, 1999.

Stramma, L., Johnson, G. C., Sprintall, J., and Mohrholz, V.: Expanding oxygen-minimum zones in the tropical oceans, Science, 320, 655-658, 2008.

Stramma, L., Bange, H. W., Czeschel, R., Lorenzo, A., and Frank, M.: On the role of mesoscale eddies for the biological productivity and biogeochemistry in the eastern tropical Pacific Ocean off Peru, Biogeosciences, 10, 7293-7306, doi:10.5194/bg-10-72932013, 2013.

Strub, P. T., Mesías, J. M., Montecino, V., Rutllant, J., and Salinas, S.: Coastal ocean circulation off western South America coastal segment (6,e), The Sea, edited by: Robinson A. R. and Brink, K. H., 11 273-313, ISBN 0-471-11545-2, 1998.

Tsuchiya, M. and Talley, L. D.: A Pacific hydrographic section at $88^{\circ} \mathrm{W}$ : Water property distribution, J. Geophys. Res., 103, 12899-12918, 1998.

Ulloa, O., Escribano, R., Hormazabal, S., Quiñones, R. A., González, R. R., and Ramos, M.: Evolution and biological effects of the 1997-98 El Niño in the upwelling ecosystem off northern Chile, Geophys. Res. Lett., 28, 1591-1594, 2001.

Vergara, O., Dewitte, B., Montes, I., Garçon, V., Ramos, M., Paulmier, A., and Pizarro, O.: Seasonal Variability of the Oxygen Minimum Zone off Peru in a high-resolution regional coupled model, Biogeosciences Discuss., doi:10.5194/bg-2015-631, in review, 2016.

Wang, C. and Fiedler, P. C.: ENSO variability in the eastern tropical Pacific: A review, Prog. Oceanogr., 69, 239-266, 2006.

Ward, B. B.: Nitrification in marine systems, in: Nitrogen in the Marine Environment, edited by: Capone, D. G., Bronk, D. A., Mulholland, M. R., and Carpenter, E. J., 2nd Edn., Elsevier, Amsterdam, 199-261, 2008.

Winkler, L. W.: Bestimmung des im Wasser gelösten Sauerstoffs, Ber. Dtsch. Chem. Ges., 21, 2843-2855, 1888. 